Editorial

\title{
Se ninguém me perguntar, eu sei. Se me perguntarem, ignoro
}

Há três meses recebi um e-mail me convidando para participar, como conferencista, do XIX Congresso Brasileiro de Fisioterapia, realizado, em Florianópolis, entre 9 e 12 de outubro. Não fosse pelo tema que me propuseram: Estratégias de Marketing, o convite não deveria ter me causado surpresa porque, ainda que já estivesse aposentado, participei no passado de muitos congressos nas áreas de fisioterapia, de educaçáo física e da medicina. Imaginei a pergunta que as pessoas que me conheciam fariam ao me ver falando sobre Marketing em um congresso de fisioterapia ou fosse lá onde fosse. Afinal, dediquei todos os meus quarenta anos de vida acadêmica à pesquisa, ao ensino da biomecânica e da epidemiologia, e nunca havia tido contato com áreas afins ao marketing.

O obvio apontava para uma recusa imediata ao convite. Mas como ao longo de minha vida aprendi que a obviedade esconde algumas armadilhas, e, às vezes, é mais burra do que a própria unanimidade, resolvi me conceder um par de dias, antes de me pronunciar sobre o tema.

Após algumas ponderações, vi que havia três maneiras de responder ao citado convite. A primeira delas, já citada aqui, seria a recusa, justificada pelo fato de não reunir as habilidades necessárias. A segunda alternativa, seria a de aceitar o convite amparando-me no que disse Santo Agostinho: "O que é o tempo? Se não me perguntarem eu sei. Se me perguntarem, ignoro". Essa alternativa caiu por terra, porque motivos muito claros, que não merecem aqui uma abordagem.

A terceira e ultima opção, também seria a de aceitar, buscando socorro no meu novo ofício: a de escritor ficcionista. Há alguns anos já havia penetrado no mundo ficcional, e agora, no terceiro romance, com contrato com uma editora de São Paulo, já me sentia seguro para criar um personagem, por acaso um fisioterapeuta, cuja trajetória de sucesso, consolidada em açôes previamente estabelecidas, seria analisada na conferência. Me convenci que seria capaz de criar uma ou duas situações, que envolvessem estratégias de um marketing mínimo; entendendo-se aqui como marketing mínimo, o marketing sujeito aos código de ética dos Conselhos e Colégios profissionais.
Contei entáo a historia do Dr. X., fisioterapeuta que queria viajar para a Europa mas não possuía recursos. Ele começou então a definir as metas e a produzir os planos de ações, que o permitissem atingir seu objetivo. Pensou consigo mesmo: "Poderia oferecer meus serviços em troca da passagem aérea, hospedagem e alimentaçáo". Mas o que oferecer? disse ele para si mesmo. Após uma análise de seu potencial, concluiu que poderia ministrar um curso na sua área de competência. Afinal ele vislumbrara há alguns anos atrás, um campo de conhecimento ainda pouco explorado e se preparara para um dia utilizar àquela formação. Ele tivera uma visão do futuro e se aproveitaria dela agora. $O$ próximo passo seria identificar os nichos de mercado, no seu caso, locais onde poderia oferecer o seu curso. Uma vez identificado o mercado, teria que abordar esse mercado, fazendo a sua proposta. Conseguiu os endereços de Universidades, Faculdades e Associaçôes que poderiam se interessar pelo seu tema e elaborou um documento com o programa do curso e a sua proposta. Ouviu muitas críticas de colegas que lhe diziam: "Você está louco homem? Acha que vão dar importância para um curso de alguém que não conhecem e que ainda por cima está na América do Sul". Para esses sempre dizia: "O máximo que pode ocorrer é que digam náo." Dois meses após o envio da primeira proposta, o Dr. X estava viajando para Barcelona onde ministraria o seu primeiro curso. Daí por diante, o ele teve oportunidade para estar em várias cidades da Europa, ministrando cursos e participando de outros eventos similares. Na palestra abordei outros casos de sucesso; mas a falta de espaço não me permite traze-los aqui. Náo se pode deixar de considerar que o sucesso duradouro de uma estratégia de marketing está condicionado a um bom planejamento da carreira profissional e sobretudo a confiança que cada um tem de si mesmo.

Para a reflexão de meus queridos leitores, termino com Bergson: "Tem se, portanto, razão em dizer que o que fazemos depende daquilo que somos; mas deve-se acrescentar que, em certa medida, somos o que fazemos e que nos criamos continuamente a nós mesmos. 